\title{
The Effect of Implementing Paikem Case-Based Learning And Cooperative Learning On Learning Competency And Quality
}

\author{
Indrayati*, Basuki Rahmat, Apit Miharso \\ Accounting Program, Politeknik Negeri Malang, Indonesia
}

\begin{abstract}
:
Financial PKA (Praktek Kerja Akuntansi/ Accounting Work Practices) at State Polytechnic of Malang is expected to fulfill the cognitive, psychomotor, and affective aspects. Therefore, in the current learning, the researchers developed a new method namely PAIKEM through student-centered learning, case-based learning, and cooperative learning for learning competence and quality. This research aimed at developing and implementing PAIKEM method through student-centered learning, case-based learning, and cooperative learning so that the learning in the accounting department at State Polytechnic of Malang can generate high-quality human resources. The research method conducted was applied-quantitative research method and descriptive research with a classroom action research, primary data source, data processing using multiple linear regression using classical assumption test, t-test, F-test, and R square. The researchers identified the problems in the classroom, observing the field, then constructed a case plane for practicing solving a problem in real life, learning with a collaboration method. The emerged problems were analyzed and solved by the students with the ability based on the existing theory. The research finding were there was a significant effect of case-based learning, cooperative learning, and effective learning on learning competency and coefficient of determination as much as 0.621 and a significant effect of student-centered learning, cooperative learning, creative learning, and effective learning ton the learning quality with the coefficient of determination as much as 0.744 .
\end{abstract}

Keywords: Case-based learning, cooperative learning, competency, quality

DOI: $10.7176 / \mathrm{JEP} / 10-13-10$

Publication date:May $31^{\text {st }} 2019$

\section{INTRODUCTION}

State Polytechnic of Malang is a higher education with a professional education background which prioritizes its improvement on skill application or to prepare the students to be citizens with professional abilities which can apply, develop, and disseminate their knowledge and technology as well as have an adequate skill. The accounting study program is one of the departments at State Polytechnic of Malang which holds the responsibilities to generate graduates who are ready to work, skillful in the accounting field, and able to compete in the global market according to their vision and mission.

The assessment on the educational product quality is firstly observed from the development of basic attitudes such as scientific academic critical behavior and the willingness to seek the truth continuously (Yumarma, 2006). Therefore, the concept of education is not reduced on the tests which only measure the transfer of knowledge (cognitive), but broader including the shaping of skills (psychomotor) and basic attitude or affective, such as criticality, creativity, and openness on innovation and various discoveries. All of them are significantly required so that students can survive and answer dynamic challenges. In this case, educators are demanded not only as knowledge transferrer, but also beyond that which is as agents of enlightenment.

Helts 2003-2010 mandated by Directorate General of Higher Education in April 2003 gave trust, one of which is the application of Student-Centered Learning (SCL) principles in the learning process. There are various learning methods in Student-Centered Learning (SCL), among them are Case-based Learning, Cooperative Learning, and Project-based Learning.

Currently, the learning process which is commonly practiced is in the form of lecturing. This method of learning pattern in which a passive lecturer and passive students have low learning effectiveness. Therefore, current learning method cannot sharpen the students' analysis ability and awareness of problems, train problem solving and ability to evaluate a problem holistically. Hence, a new method namely case-based learning PAIKEM is developed. The following is the score of Financial PKA course before the PAIKEM method was applied.

Table 1. The percentage of students' ability in Financial PKA course in 2018 (Total students: 400)

\begin{tabular}{|l|l|}
\hline Final score & Financial PKA course \\
\hline A & $30 \%$ \\
\hline B + & $23 \%$ \\
\hline B & $10 \%$ \\
\hline C + & $20 \%$ \\
\hline C & $7 \%$ \\
\hline D & $10 \%$ \\
\hline
\end{tabular}


Based on Table 1, the traditional learning method in Financial PKA course contributes A score as much as 30\%, $\mathrm{B}+$ score as much as $23 \%$, B score as much as $10 \%, \mathrm{C}+$ score as much as $20 \%, \mathrm{C}$ score as much as $7 \%$ and D score as much as $10 \%$. Therefore, according to HELTS, the new learning strategy which will be used for learning is based on student-centered learning with the implementation of case-based learning and cooperative learning for Financial PKA course to improve students' competency.

\section{LITERATURE REVIEW}

The research on students' active learning and cooperative learning have been conducted by Felder and Brant (1996) who stated that this approach improves motivation for learning, knowledge memory, the depth of understanding, and the appreciation on the taught subject. The research also shows that the cooperative learning practice directs the students on achieving higher achievements, more efficient, and more effective process of information exchange, improving productivity, a positive relationship among students, and fostering trustworthy among friends, compared to competitive and/or individualistic learning experiences.

\section{PAIKEM learning concept}

PAIKEM is an abbreviation from Pembelajaran Aktif, Inovatif, Kreatif, Efektif, dan Menyenangkan which means active, innovative, creative, effective and fun learning. Active is defined as in the learning process, teachers/ lecturers must create a specific condition so that the students ask questions actively, questioning, and express their ideas.

According to Ahmadi (2011:30), PAIKEM is active, innovative, creative, effective and fun learning. According to Syah and Kariadinata (2009:1), PAIKEM is the abbreviation of Pembelajaran Aktif, Inovatif, Kreatif, Efektif dan Menyenangkan which means active, innovative, creative, effective and fun learning. Furthermore, PAIKEM can be defined as an approach to teaching which is used along with a specific method and various teaching media and environmental management in such a way that the learning process becomes active, innovative, creative, effective and fun. The purpose of each of the words PAIKEM according to Suparlan et al. (2008:70) are as follows.

1. Active means in the learning process, the teacher/ lecturer must create a condition in such a way so that the students actively ask questions, express ideas, and solving problems.

2. Innovative means teacher/ lecturer must create new learning condition and learning activities according to the demands and educational development such as the use of project-based-learning, cooperativelearning, and case-based-learning.

3. Creative means that teachers create diverse learning activities to fulfill various levels of students' ability or students' creativities in problem-solving.

4. Effective means generating what needs to be mastered by the students after the learning process which is achieving the predetermined objective/ competency.

5. Fun means that teacher/ lecturer must be able to create fun and not boring teaching and learning conditions so that the students can obtain a sharp focus and the learning can be faster such as the availability of teaching aids and handout in learning, as well as the use of multimedia and website.

According to Tarmizi (2009), PAIKEM is the abbreviation of active, creative, effective, and fun learning. Active means in the learning process, the teacher/ lecturer must create the condition in such a way so that the students can be active, ask questions, questioning, express ideas, and solve problems. Innovative learning can adapt fun learning models such as project-based learning, cooperative learning, case-based learning, and the use of multimedia and teaching aids.

PAIKEM method is one of the ideal learning models. PAIKEM method helps students obtain their ideas in learning through the approach of the surrounding environment. The positive impact of implementing PAIKEM model is that the students can be encouraged in terms of their curiosity in their surroundings. If we reflect on the four pillars of education, they are learning to how, learning to be, learning to do, and learning to live together.

To create an effective learning situation, Combs (1976) asserts that three characteristics are required, namely:

1. Conducive atmosphere to explore the meaning of learning. The students must feel safe and accepted. They want to understand the risks and benefits of obtaining knowledge and new understanding. The class must be conducive for involvement, interaction, and socialization with an approach similar to the business world.

2. Students must be given opportunities to find new information and experience. These opportunities are given not only in the form of information but also encouragement for students to find information. 
3. New understanding must be obtained by the students through the personal discovery process. The method used must be personal and according to their personality and the student's learning style.

\section{Case-based learning}

Several aspects differentiating cooperative-based learning and traditional learning are described by Thomas, Mergendoller, \& Michaelson (1999) as shown in Table 2.

Table 2. The Difference between Case-based Learning and Traditional Learning

\begin{tabular}{|c|c|c|}
\hline EDUCATIONAL ASPECT & TRADITIONAL EMPHASIS & CASE EMPHASIS \\
\hline \multirow[t]{3}{*}{ Curriculum Focus } & Content coverage & The depth of knowledge \\
\hline & Knowledge on Facts & $\begin{array}{l}\text { The mastery of concepts and } \\
\text { principles }\end{array}$ \\
\hline & $\begin{array}{l}\text { Learning "building-block" skill in } \\
\text { isolation }\end{array}$ & $\begin{array}{l}\text { The development of complex } \\
\text { problem-solving skill }\end{array}$ \\
\hline \multirow[t]{3}{*}{ Scope and Sequence } & $\begin{array}{l}\text { Following the sequence of } \\
\text { curriculum strictly }\end{array}$ & Following the learning interest \\
\hline & $\begin{array}{l}\text { Progressing from block to block or } \\
\text { unit to unit }\end{array}$ & $\begin{array}{l}\text { Big units formed from the complex } \\
\text { cases and issues }\end{array}$ \\
\hline & Centered, discipline-base focus & Broadening, interdisciplinary focus \\
\hline \multirow[t]{2}{*}{ Role of teacher/ lecturer } & Lecturer and director of learning & $\begin{array}{l}\text { Learning source provider and } \\
\text { participant in learning activities }\end{array}$ \\
\hline & Expert & Supervisor/ partner \\
\hline \multirow[t]{4}{*}{ Measurement focus } & Product & Process and product \\
\hline & Test score & Real achievement \\
\hline & Comparing with others & $\begin{array}{l}\text { Standard performance and progress } \\
\text { over time }\end{array}$ \\
\hline & Reproduction of Information & Understanding demonstration \\
\hline \multirow[t]{2}{*}{ Learning materials } & Text, lecture, and presentation & $\begin{array}{l}\text { Direct original sources: printed } \\
\text { materials, interviews, documents, etc. }\end{array}$ \\
\hline & $\begin{array}{l}\text { Activities and worksheet developed } \\
\text { by teachers }\end{array}$ & $\begin{array}{l}\text { Data and materials developed by the } \\
\text { students }\end{array}$ \\
\hline \multirow[t]{3}{*}{ Technology usage } & Supporter, peripheral & Primary, integral \\
\hline & Implemented by the teacher & Directed by students \\
\hline & $\begin{array}{l}\text { Aimed at broadening teacher's } \\
\text { presentation }\end{array}$ & $\begin{array}{l}\text { Usability for expanding student } \\
\text { presentations or strengthening } \\
\text { student abilities }\end{array}$ \\
\hline \multirow[t]{3}{*}{ Class context } & Students work independently & Students work in groups \\
\hline & Students compete with each other & Students collaborate one and another \\
\hline & $\begin{array}{l}\text { Students receive information from } \\
\text { the teacher }\end{array}$ & $\begin{array}{l}\text { Students construct, contribute, and } \\
\text { synthesis the information }\end{array}$ \\
\hline \multirow[t]{3}{*}{ Role of students } & Carry out teacher's orders & $\begin{array}{l}\text { Conducting learning activities } \\
\text { directed by themselves }\end{array}$ \\
\hline & Reminder and repeater of facts & $\begin{array}{l}\text { Reviewers, integrators, and } \\
\text { presenters of ideas }\end{array}$ \\
\hline & $\begin{array}{l}\text { Students receive and complete short } \\
\text { report assignment }\end{array}$ & $\begin{array}{l}\text { Students receive assignments and } \\
\text { work independently in an abundant } \\
\text { time }\end{array}$ \\
\hline Short-term goals & $\begin{array}{l}\text { Knowledge on facts, terms, and } \\
\text { content }\end{array}$ & $\begin{array}{l}\text { Understanding and application of } \\
\text { complex ideas and processes }\end{array}$ \\
\hline Long-term goals & $\begin{array}{l}\text { The breadth of knowledge of the } \\
\text { graduates who are successful in the } \\
\text { learning achievement standard test }\end{array}$ & $\begin{array}{l}\text { In knowledge, Graduates who have } \\
\text { character and are skilled at } \\
\text { developing themselves, } \\
\text { independently, and learning } \\
\text { throughout their lives. }\end{array}$ \\
\hline
\end{tabular}




\section{RESEARCH METHOD}

\section{Research design: Classroom action research}

One of the popular definitions of classroom action research by Lewin's model is interpreted by Kemmis and Carr (2005). Both authors state that classroom action research is a reflective form of research performed by the researcher in society and aim at improving their work, understanding the work and situation, as well as this work, is conducted, including in the field of education. (Kemmis \& Carr, 2005). Classroom action research is described as a dynamic process in which the four aspects are planning, acting, observing, and reflecting must be understood as non-static stages, auto-completed, but more of moments in the spiral form related to planning, acting, observing, and reflecting.

\section{Figure 1. the Action Research Spiral by Kemmis \& Taggart (1988)}

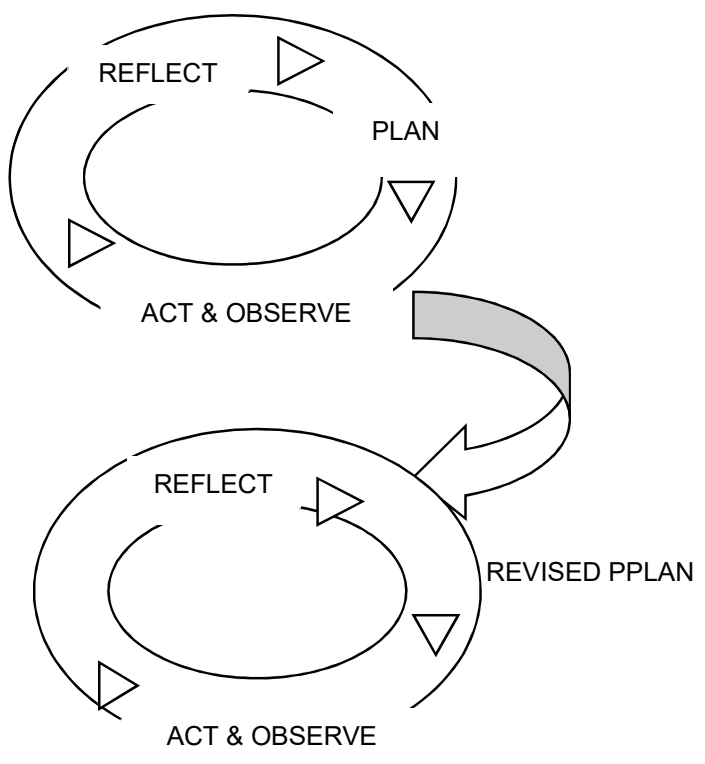

Classroom action research according to Moleong, 2006 is as follow:

1. Identifying a problem, which is identifying the occurring problems in the classroom.

2. Discussing a problem, discussing the problem with the team to find a solution.

3. Reviewing a problem, reviewing the problems by seeking alternative problem-solving.

4. Redefinition of a problem, redefining the occurring problem to find the solution through problemsolving.

5. Selecting a method, conducting learning method selection to find the appropriate way method.

6. Implementing a change, implementing a change of the old method to the new one.

In the management of Financial PKA learning, assessment or evaluation on students are also conducted by the lecturer using the method suggested by Michaelson (1998) which is classifying the assessment criteria into three performance areas, namely: 1) individual performance, 2) group performance and 3) performance of individual contribution to group (measured using peer-evaluation sheet).

\section{RESULTS AND DISCUSSION}

The research results of implementing modified learning model in Financial PKA course is the production of PAIKEM new learning method development through case-based learning and competency, the learning quality of Financial PKA course, lesson study (RPS), and the construction of Financial PKA course syllabus, GBPP, SAP, teaching materials using power point and animation. 
Table 3. The percentage of assessment results on the ranking of students participating in Financial PKA course

\begin{tabular}{|l|l|}
\hline Score & Financial PKA Course \\
\hline A & $80 \%$ \\
\hline B + & $10 \%$ \\
\hline B & $5 \%$ \\
\hline C + & $5 \%$ \\
\hline C & - \\
\hline D & - \\
\hline
\end{tabular}

Students who obtained A score are $85 \%$, B+ score of $10 \%$, B score of $5 \%$, and C+ score of $5 \%$. Meanwhile, the students' response to the new learning model in Financial PKA course namely case-based learning was $95 \%$ agreed on the implementation of PAIKEM learning model since this learning made the students active, innovative, effective, and fun, more competent, understand the Financial PKA course well in the knowledge and skills, while the other $5 \%$ perceived that they preferred the traditional learning method which was lecture method.

This method implemented a new learning method on Financial PKA course through case-based learning and the utilization of teaching materials, exercises, multimedia teaching aids, and the distribution of cases or assignment to complete the questions on the application of financial accounting in the company.

The questions were based on the previously taught theory and concepts or according to the competency-based curriculum (KKNI), teaching materials made by the lecturer. The completion of cases regarding the application of accounting questions will be significantly helpful for companies in making a financial report, calculation of the cost of production and cost of goods sold, income statement, PKA Finance with the PAIKEM method are easier to understand and solve problems in the real world. Learning becomes easier and not boring, the students understand more about theory, and then solve problems in the real world so that cognitive, psychomotor and affective aspects can be achieved.

The statistical test results showed that the effects of case-based PAIKEM method on learning competency are as follows.

1. Validity and reliability tests. Validity test showed that if the coefficient of correlation between the score of an indicator is higher than 0.3 , then the instrument is stated as valid, while the reliability test showed that if the Cronbach's alpha shows a higher number than 0.6, then the instrument is stated as reliable.

Table 4. The validity test of questionnaire on Variable $X$

\begin{tabular}{||c|c|c|c||}
\hline Item & $\mathbf{r}$ & Significance & Description \\
\hline $\mathrm{X} 1$ & 0.805 & 0.000 & Valid \\
\hline $\mathrm{X} 2$ & 0.798 & 0.000 & Valid \\
\hline $\mathrm{X} 3$ & 0.806 & 0.000 & Valid \\
\hline $\mathrm{X} 4$ & 0.828 & 0.000 & Valid \\
\hline $\mathrm{X} 5$ & 0.842 & 0.000 & Valid \\
\hline $\mathrm{X} 6$ & 0.828 & 0.000 & Valid \\
\hline $\mathrm{X} 7$ & 0.768 & 0.000 & Valid \\
\hline
\end{tabular}

Table 5. The validity test of questionnaire on Variable $Y$

\begin{tabular}{||c|c|c|c||}
\hline Item & $\mathbf{r}$ & Significance & Description \\
\hline Y1 & 0.873 & 0.000 & Valid \\
\hline Y2 & 0.864 & 0.000 & Valid \\
\hline Y3 & 0.843 & 0.000 & Valid \\
\hline Y4 & 0.890 & 0.000 & Valid \\
\hline
\end{tabular}


Table 6. The Reliability Test of Variables

\begin{tabular}{|c|l|l|l|}
\hline Variable & item & Alpha Coefficient & Description \\
\hline $\mathrm{X}$ & 7 & 0.912 & Reliable \\
\hline $\mathrm{Y}$ & 4 & 0.889 & Reliable \\
\hline
\end{tabular}

2. Classical assumption test on the effect of $X$ on $Y$ shows that the normality test using KolmogorovSmirnov showed normal data, no multicollinearity, no heteroskedasticity, and no autocorrelation.

3. Multiple Regression Analysis

The multiple linear analysis results are shown in Table 7.

Table 7. The Summary of Multiple Linear Regression Test

\begin{tabular}{|l|c|c|c|c|}
\hline \multicolumn{1}{|c|}{ Variable } & $\boldsymbol{B}$ & $\mathbf{T}_{\text {count }}$ & Significant & Description \\
\hline Constant & 0.698 & & & \\
\hline TCL (X1) & -0.034 & -0.441 & 0.659 & Not Significant \\
\hline SAL (X2) & 0.089 & 1.308 & 0.193 & Not Significant \\
\hline CBL (X3) & 0.273 & 4.504 & 0.000 & Significant \\
\hline Coop_L (X4) & 0.187 & 2.923 & 0.004 & Significant \\
\hline Cre-L (X5) & 0.083 & 1.270 & 0.206 & Not Significant \\
\hline Ef-L (X6) & 0.182 & 2.585 & 0.011 & Significant \\
\hline Fun-L (X7) & 0.040 & 0.744 & 0.458 & Not Significant \\
\hline$\alpha$ & $=0.050$ & \\
Coefficient of Determination $\left(\mathrm{R}^{2}\right)$ & $=0.621$ & \\
F-count & $=40.176$ \\
F-table ( $\left.\mathrm{F}_{7,172,0.05}\right)$ & $=2.063$ \\
F significance & $=0.000$ \\
t-table ( $\left.\mathrm{t}_{172,0.05}\right)$ & $=1.974$ & \\
\hline
\end{tabular}

Based on Table 4.8, the regression model obtained is as follow.

$\mathrm{Y}=0.698-0.034 \times 1+0.089 \times 2+0.273 \times 3+0.187 \times 4+0.083 \times 5+0.182 \times 6$

$+0.040 \times 7+\mathbf{e}_{\mathbf{i}}$

\section{F-test (Simultaneous test / joint influence)}

Based on Table 7, the score of $F_{\text {count }}$ is higher than $F_{\text {table }}(40.176>2.063)$ and has a smaller significance value than $\alpha(0.000<0.050)$, so that $\mathbf{H}_{0}$ is rejected. It means that simultaneously, the independent variables namely X1 (TCL), X2 (SAL), X3(PBL), X4(Coop_L), X5(Cre-L), X6(Ef-L), and X7 (Fun-L) has a significant effect on Y1 variable (Competency).

\section{T-test (Partial test/ each influence)}

Based on Table 7, the results are as follows:

a. X1 (TCL) variable has a negative and not significant effect on Y1 variable (Competency). Observed from the t-test statistics with a smaller $\left|\mathrm{t}_{\text {count }}\right|$ than $\mathrm{t}_{\text {table }}(0.441<1.974)$ and higher $\mathrm{t}$ significant value than $\alpha$ $(0.659>0.050)$. This test showed the decision that $\mathbf{H}_{0}$ was accepted. The negative coefficient showed that the increase in $\mathrm{X} 1$ variable decreased $\mathrm{Y} 1$ variable but not significantly.

b. X2(SAL) variable has a positive and not significant effect on Y1 variable (Competency). Observed from the $\mathrm{t}$-test statistics with a smaller $\left|\mathrm{t}_{\text {count }}\right|$ than $\mathrm{t}_{\text {table }}(1.308<1.974)$ and higher $\mathrm{t}$ significant value than $\alpha(0.193>0.050)$. This test showed the decision that $\mathbf{H}_{0}$ was accepted. The negative coefficient showed that the increase in $\mathrm{X} 2$ variable could increase $\mathrm{Y} 1$ variable but not significantly.

c. $\mathrm{X} 3(\mathrm{CBL})$ variable has a positive and significant effect on Y1 variable (Competency). Observed from the ttest statistics with a higher $\left|t_{\text {count }}\right|$ than $t_{\text {table }}(4.504>1.974)$ and smaller $t$ significant value than $\alpha(0.000$ $<0.050$ ). This test showed the decision that $\mathbf{H}_{0}$ was rejected. The positive coefficient showed that the increase in X3 variable could increase Y1 variable significantly.

d. X4(Coop_L) variable has a positive and significant effect on Y1 variable (Competency). Observed from the $\mathrm{t}$-test statistics with a higher $\left|t_{\text {count }}\right|$ than $t_{\text {table }}(2.923>1.974)$ and smaller $t$ significant value than $\alpha(0.004$ 
$<0.050$ ). This test showed the decision that $\mathbf{H}_{0}$ was rejected. The positive coefficient showed that the increase in $\mathrm{X} 4$ variable could increase $\mathrm{Y} 1$ variable significantly.

e. X5(Cre-L) variable has a positive and not significant effect on Y1 variable (Competency). Observed from the t-test statistics with a smaller $\left|\mathrm{t}_{\text {count }}\right|$ than $\mathrm{t}_{\text {table }}(1.270<1.974)$ and higher $\mathrm{t}$ significant value than $\alpha(0.206$ $>0.050$ ). This test showed the decision that $\mathbf{H}_{0}$ was accepted. The positive coefficient showed that the increase in X5 variable could increase Y1 variable but not significantly.

f. X6(Ef-L) variable has a positive and significant effect on Y1 variable (Competency). Observed from the ttest statistics with a higher $\left|t_{\text {count }}\right|$ than $t_{\text {table }}(2.585>1.974)$ and smaller $t$ significant value than $\alpha(0.011<0.050)$. This test showed the decision that $\mathbf{H}_{0}$ was rejected. The positive coefficient showed that the increase in $\mathrm{X} 6$ variable could increase $\mathrm{Y} 1$ variable significantly.

g. X7(Fun-L) variable has a positive and not significant effect on Y1 variable (Competency). Observed from the t-test statistics with a smaller $\left|\mathrm{t}_{\text {count }}\right|$ than $\mathrm{t}_{\text {table }}(0.744<1.974)$ and higher $\mathrm{t}$ significant value than $\alpha(0.458>0.050)$. This test showed the decision that $\mathbf{H}_{0}$ was accepted. The positive coefficient showed that the increase in $\mathrm{X} 7$ variable could increase $\mathrm{Y} 1$ variable but not significantly.

Coefficient of Determination $\left(R^{2}\right)$

The amount of contribution from the independent variables simultaneously on dependent variables is based on the calculation results in Table 4.5 with the coefficient of determination (R Square) of 0.621. the results explained that the contribution of independent variables namely (X1 (TCL), X2 (SAL), X3(CBL), X4(Coop_L), $\mathrm{X} 5(\mathrm{Cre}-\mathrm{L}), \mathrm{X} 6$ (Ef-L), and X7 (Fun-L)) involved in the regression equation on Y1 variable (Competency) was $62.1 \%$, while another $37.9 \%$ was contributed by other variables uninvolved in this equation.

The classical assumption on the effect of $\mathrm{X}$ on Y2 (quality) showed that normal data did not show the presence of multicollinearity, heteroskedasticity, and autocorrelation.

Multiple Regression Analysis

The regression results of $\mathrm{X}$ influence on $\mathrm{Y} 2$ is shown in Table 4.6 as the following.

Table 8. Summary of Multiple Linear Regression Testing

\begin{tabular}{|l|c|c|c|c|}
\hline \multicolumn{1}{|c|}{ Variable } & $\boldsymbol{B}$ & $\mathbf{T}_{\text {count }}$ & Significant & Description \\
\hline Constant & 0.615 & & & \\
\hline TCL (X1) & -0.102 & -1.706 & 0.090 & Not Significant \\
\hline SAL (X2) & 0.262 & 4.987 & 0.000 & Significant \\
\hline CBL (X3) & 0.076 & 1.608 & 0.110 & Not Significant \\
\hline Coop L (X4) & 0.106 & 2.150 & 0.033 & Significant \\
\hline Cre-L (X5) & 0.164 & 3.244 & 0.001 & Significant \\
\hline Ef-L (X6) & 0.274 & 5.037 & 0.000 & Significant \\
\hline Fun-L (X7) & 0.063 & 1.508 & 0.133 & Not Significant \\
\hline$\alpha$ & $=0.050$ & \\
Coefficient of Determination $\left(\mathrm{R}^{2}\right)$ & $=0.744$ & \\
F-count & $=71.299$ & \\
F-table (F & & & \\
F significance & $=2.063$ & \\
t-table $\left(\mathrm{t}_{172,0.05}\right)$ & $=0.000$ \\
\hline
\end{tabular}

Based on Table 8, the regression model obtained is as follow.

$Y=0.615-0.102 \times 1+0.262 \times 2+0.076 \times 3+0.106 \times 4+0.164 \times 5+0.274 \times 6$

$+0.063 \times 7+e_{i}$

F-test (Simultaneous test / joint influence)

Based on Table 8, the score of $F_{\text {count }}$ is higher than $F_{\text {table }}(71.299>2.063)$ and has a smaller significance value than $\alpha(0.000<0.050)$, so that $\mathbf{H}_{\mathbf{0}}$ was rejected. It means that simultaneously, the independent variables namely X1 (TCL), X2 (SAL), X3(CBL), X4(Coop_L), X5(Cre-L), X6(Ef-L), and X7 (Fun-L) have a significant effect on Y2 variable (quality).

T-test (Partial Test/ each influence)

Based on Table 8, the results are as follows: 
a. X1 (TCL) variable has a negative and not significant effect on Y2 variable (Quality). Observed from the ttest statistics with a smaller $\left|t_{\text {count }}\right|$ than $\left.t_{\text {table }} 1.706<1.974\right)$ and higher $t$ significant value than $\alpha(0.090>0.050)$. This test showed the decision that $\mathbf{H}_{0}$ was accepted. The negative coefficient showed that the increase in $\mathrm{X} 1$ variable decreased $\mathrm{Y} 2$ variable but not significantly.

b. X2(SAL) variable has a positive and significant effect on Y2 variable (Quality). Observed from the t-test statistics with a higher $\left|t_{\text {count }}\right|$ than $t_{\text {table }}(4.987>1.974)$ and smaller $t$ significant value than $\alpha(0.000<0.050)$. This test showed the decision that $\mathbf{H}_{0}$ was rejected. The positive coefficient showed that the increase in $\mathrm{X} 2$ variable could increase $\mathrm{Y} 2$ variable significantly.

c. $\mathrm{X} 3(\mathrm{CBL})$ variable has a positive and not significant effect on Y2 variable (Quality). Observed from the ttest statistics with a smaller $\left|t_{\text {count }}\right|$ than $t_{\text {table }}(1.608<1.974)$ and higher $t$ significant value than $\alpha(0.110>0.050)$. This test showed the decision that $\mathbf{H}_{0}$ was accepted. The positive coefficient showed that the increase in X3 variable could increase Y2 variable but not significantly.

d. X4(Coop_L) variable has a positive and significant effect on Y2 variable (Quality). Observed from the ttest statistics with a higher $\left|t_{\text {count }}\right|$ than $t_{\text {table }}(2.150>1.974)$ and smaller $t$ significant value than $\alpha(0.033<0.050)$. This test showed the decision that $\mathrm{H}_{0}$ was rejected. The positive coefficient showed that the increase in $\mathrm{X} 4$ variable could increase $\mathrm{Y} 2$ variable significantly.

e. X5(Cre-L) variable has a positive and significant effect on Y2 variable (Quality). Observed from the t-test statistics with a higher $\left|t_{\text {count }}\right|$ than $t_{\text {table }}(3.244>1.974)$ and smaller $t$ significant value than $\alpha(0.001<0.050)$. This test showed the decision that $\mathbf{H}_{0}$ was rejected. The positive coefficient showed that the increase in X5 variable could increase $\mathrm{Y} 2$ variable significantly.

f. X6(Ef-L) variable has a positive and significant effect on Y2 variable (Quality). Observed from the t-test statistics with a higher $\left|t_{\text {count }}\right|$ than $t_{\text {table }}(5.037>1.974)$ and smaller $t$ significant value than $\alpha(0.000<0.050)$.

This test showed the decision that $\mathrm{H}_{0}$ was rejected. The positive coefficient showed that the increase in X6 variable could increase $\mathrm{Y} 2$ variable significantly.

g. X7(Fun-L) variable has a positive and not significant effect on Y2 variable (Quality). Observed from the ttest statistics with a smaller $\left|t_{\text {count }}\right|$ than $\mathrm{t}_{\text {table }}(1.508<1.974)$ and higher $\mathrm{t}$ significant value than $\alpha(0.133>0.050)$. This test showed the decision that $\mathbf{H}_{0}$ was accepted. The positive coefficient showed that the increase in X7 variable could increase Y2 variable but not significantly.

Coefficient of Determination $\left(R^{2}\right)$

The amount of contribution from independent variables simultaneously on dependent variables based on the calculation in Table 4.6 with the coefficient of determination (R-Square) is as much as 0.744 . The results describe the contribution from independent variables namely (X1 (TCL), X2 (SAL), X3(CBL), X4(Coop_L), $\mathrm{X} 5$ (Cre-L), X6(Ef-L), and X7 (Fun-L)) involved in the regression equation on Y2 variable (quality) is as much as $74.4 \%$, while another $25.6 \%$ was contributed by other variables uninvolved in this equation.

\section{Conclusion}

Based on the research results, the conclusion was drawn as follows. First, case-based learning PAIKEM learning method has been successfully applied in the vocational education namely State Polytechnique of Malang. The constructed curriculum-based learning competence (KKNI) through lesson plan (RPP) and syllabus, lesson plan in GBPP and SAP, teaching material and exercises in Financial PKA course, teaching aids using multimedia in Financial PKA learning, new learning method namely case-based learning and cooperative learning, as well as student-centered learning. The survey results showed that the students preferred taught using case-based learning method and their scores were better than before the implementation.

Second, the analysis results of the effect of $\mathrm{X}_{\mathrm{i}}$ variable on $\mathrm{Y} 1$ (Competency) showed simultaneously, independent variables of X1 (TCL), X2 (SAL), X3(CBL), X4(Coop_L), X5(Cre-L), X6(Ef-L), and X7 (Fun-L) has a significant effect on Y1 (Competency). Partially, independent variables of X3(CBL), X4(Coop_L), and X6 (Ef-L) has a significant effect on Y1 (Competency). Coefficient of determination as much as $0.621(62.1 \%)$. The analysis results of the effect of $\mathrm{X}_{\mathrm{i}}$ on Y2 (Quality) showed: Simultaneously, independent variables of X1 (TCL), X2 (SAL), X3(CBL), X4(Coop_L), X5(Cre-L), X6(Ef-L), and X7 (Fun-L) has a significant effect on Y2 (Quality). Partially, independent variables of X2 (SAL), X4(Coop_L), X5(Cre-L), and X6(Ef-L) has a significant effect on Y2 (Quality). Coefficient of determination as much as $0.744(74.4 \%)$.

\section{ACKNOWLEDGMENT}

The authors conveyed their sincere gratitude to the Director of State Polytechnic of Malang and the Ministry 
of Research, Technology, and Higher Education for the funding of this research.

\section{REFERENCES}

Anonymous, 2005, Pembelajaran Aktif, Buletin P \& P, Electronic Version, April-June.

Baer, John. 2005. Grouping and Achievement in Cooperative Learning. College Teaching. Vol. 51 No. 4.

Chong, Vineent K. 1999. Cooperative learning: The Role of Feedback and Use of Lecture Activities on Student't Academic Performance.

Cook, Ellen D. \& Hazelwood, Anita C. 2002. An Active Learning Strategy for the Classroom "Who Wants to Win Some Mini Chips Ahoy?” Journal of Accounting Education, 20 pp. 297-306.

Depdiknas. n.d. Konsep Paikem. Retrieved from http://akhmadsudrajat.wordpress.com/Bahanajar/konseppakem/feed, on November 23, 2007.

Dewajani, Sylvi. 2005. Belajar Mandiri Belajar Aktif Strategi Kognitif. Presented Paper. Pelatihan Active Learning held by PHK A3, Department of IESP, Universitas Diponegoro. 2005. Case-Based Learning. Presented Paper. Pelatihan Active Learning held by PHK A3, Department of IESP, Universitas Diponegoro.

Dit. Teknik. 2010. Pembelajaran Berbasis PAIKEM (CTL, Pembelajaran Terpadu, Pembelajaran Tematik). Jakarta: Kemendiknas.

Dale, E. 1969. Audio-Visual Methods in Teaching (3rd edition). US: Holt, Tinehart and Winston.

Handoko, Ham. 2005. Metode Kasus dalam Pengajaran (Manajemen), Presented Paper. Pelatihan Active Learning held by PHK A3, Department of IESP, Universitas Diponegoro.

Jauhar, M. 2011. Implementasi PAIKEM. Jakarta: Prestasi Pustaka.

Kemmis, S. \& Carr, W. 2005. Penelitian Tindakan Kelas. Bandung: Rosdakarya.

Kemmis, S. \& McTaggart, R. 1999. The Action Research Planner. Victoria; Deakin University Press.

Moleong, L.J. 2006, Penelitian Tindakan Kelas. Bandung: Rosdakarya.

Moleong, L.J. 2016, Metodologi Penelitian Kualitatif. Bandung: Penerbit PT Remaja Rosdakarya.

Phipps, M., Phipps, C., Kask, S., and Higgins, S. 2001. University Students' Perception of Cooperative Learning: Implications for Administrators and Instructors, Journal of Experiential Education, 24: 14-21.

Rohani, A. 2004, Pengelolaan Pengajaran. Jakarta: PT Rineka Cipta.

Suparlan, 2009, Paikem. Unpublished Dissertation. Malang: Universitas Negeri Malang.

Smith, B.L., \& MacGregor, J. 1992, Collaborative Learning; A Sourcebook for Higher Education. University Park, PA: National Center on Postsecundary Teaching, Learning and Assessment (NTCLA): 9-22.

Tim DBE2, 2007. Pengenalan Pembelajaran Efektif Dalam Mata Pelajaran Pokok, Jakarta: Accounting.

Kamdi, W, 2010, Project Based Learning, Unpublished Thesis. Malang: Universitas Negeri Malang.

Wiriatmadja, R. 2005, Metode Penelitian Tindakan Kelas, Untuk Meningkatkan Kinerja Guru dan Dosen. Bandung: Program Pasca Sarjana Universitas Pendidikan Indonesia. 